\title{
Educação e Comunicação ou Comunicação e Educação
}

\author{
DOI $10.1590 / 1809-5844201416$
}

Maria das Graças Targino*

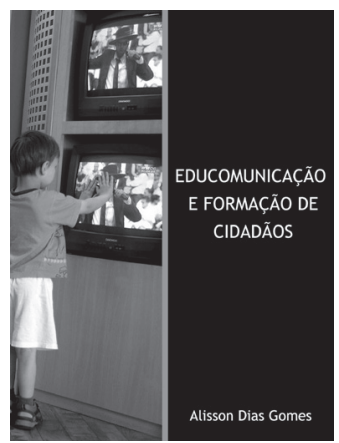

GOMES, Alisson Dias. Educomunicação e formação de cidadãos. Teresina: FSA / Halley, 2014. 368p.

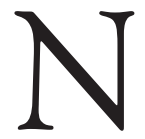

um momento histórico, em que expressões, como interdisciplinaridade, multidisciplinaridade, pluridisciplinaridade e transdisciplinaridade conquistam espaço e despertam controvérsias diante da fragilidade de suas fronteiras, a Educomunicação se fortalece mais e mais, a partir de linha teórica sólida e argumentativa, além de experiências práticas. São pioneiros, dentre outros, clássicos de diferentes procedências, a exemplo de Antoine Vallet; Francisco Gutiérrez; Kathleen Tyner; Michel Tardy; Nazareno Taddei; Peter Greenaway e Robyn Quin.

No Brasil, onde a Educomunicação é, ainda, área em expansão, há teóricos de credibilidade, como José Manuel Morán Costa, cuja tese de doutoramento (Universidade de São Paulo) sobre a temática é adotada como fonte de referência, fora e dentro do

\footnotetext{
* Professora pós-doutora em Jornalismo e doutora em Ciência da Informação. Docente do Programa de Pós-Graduação em Ciência da Informação, Universidade Federal da Paraíba, João Pessoa-PB. E-mail: gracatargino@ hotmail.com
} 
país. Aliás, é, ainda, na USP, que se registra, a partir de 2011, o Curso Licenciatura em Educomunicação. Dentre outros estudiosos, também merecem menção Hilton Japiassu e Ivani Fazenda. Aliás, o próprio Alisson Dias Gomes, autor de Educomunicação e formação de cidadãos - professor doutor em Comunicação Audiovisual junto à Universidad de Salamanca, Espanha - já na graduação, ano 2006, comprova seu interesse pela Educomunicação ao estudar a tendência de mestres do ensino médio brasileiro em recorrerem a textos da imprensa diária para trabalhar conteúdos em classe. Mais adiante, em seu doutoramento, desenvolveu a tese La película como recurso pedagógico en la formación de estudiantes de periodismo en Brasil com o objetivo macro de analisar o uso de filmes como ferramenta pedagógica no decorrer da formação integral de universitários brasileiros, em especial, nos cursos de Jornalismo.

Educomunicação e formação de cidadãos é exatamente um dos frutos da tese de Gomes, agora, à disposição da comunidade acadêmica de qualquer área e da sociedade em geral, graças à sua linguagem menos técnica e mais atraente. Além de representar forma de retorno à coletividade, é o momento de o autor fazer conhecer seu pensamento em relação à Educomunicação. Em sua visão, a relação entre Educação e Comunicação, designada, a princípio, de Pedagogia da Linguagem Total e mais conhecida, hoje, como Educomunicação, possui como fundamento a ideia da incorporação da Comunicação à Educação.

E, de fato, o autor vai bem além da discussão acerca da expressão interdisciplinaridade e similares na contemporaneidade, para dissecar a trajetória da Educomunicação, o que demanda analisar, em separado, Educação e Comunicação, até chegar à conjunção Educação + Comunicação. Obviamente, tudo isso prevê a inserção de conhecimentos sobre alfabetização midiática / audiovisual, além da formação docente e, então, especificamente, o cinema na Educomunicação. Levando em conta o corpus da pesquisa, docentes universitários, Alisson desenvolve, adiante, excelente capítulo sobre a evolução do ensino superior no Brasil. Nesse momento, enfatiza medidas de renovação (algumas das quais controversas) empreendidas pelo Governo Federal, à semelhança 
do Exame Nacional do Ensino Médio, Programa Universidade para Todos, Programa Ciência sem Fronteiras e Sistema de Cotas, detendo-se, com profundidade, no ensino do jornalismo em território nacional.

Os caminhos metodológicos, bastante detalhados de forma a permitir a replicação da pesquisa por outros estudiosos, suscitam a curiosidade do leitor em adentrar nos resultados obtidos e nas inferências, respectivamente capítulos seis e sete. Dentre as conclusões, o autor comprova quantitativamente e, também, mediante análise qualitativa que a Educomunicação consiste nas duas instâncias - ensino público e ensino privado - em realidade incontestável com diferenças sutis ou quase imperceptíveis diante das variáveis estudadas. Dentre estas, destacam-se: motivação para o uso de filmes; gênero preferido; critérios de seleção; formas de utilização; contribuição do material no desenvolvimento dos educandos / efeitos provocados etc.

Talvez inspirado em Ambròs e Breu, que oferece propostas didáticas para o iniciante na aprendizagem do cinema como matéria de estudo e como eixo central de aprendizagens interdisciplinares e / ou em Noguera Tajadura, que investe em atividades práticas na disciplina história do cinema, o autor do livro ora resenhado, finaliza seu trabalho de forma exemplar. Lista 80 filmes sobre a temática jornalística em diferentes perspectivas, concretizando a Educomunicação como fio condutor do dia a dia do jornalista. Cada título traz a indicação de elementos básicos referentes à ficha técnica mais o tema ou disciplina em que é possível sua utilização, chamando atenção de que se trata de mera sugestão, uma vez que os docentes podem descobrir novas formas de aplicação dos filmes em sala de aula.

Sem dúvidas, além de conjugar teoria e prática ao longo de seu texto, o autor de Educomunicação e formação de cidadãos, sem fazer apologia gratuita à Educomunicação, chama atenção para a relevância de sua expansão, numa sociedade em que Comunicação e Educação (ou Educação e Comunicação) são elementos essenciais à sobrevivência de quaisquer indivíduos e profissionais. 